\title{
Rhizobium galegae, a New Species of Legume Root Nodule Bacteria
}

\author{
KRISTINA LINDSTRÖM \\ Department of Microbiology, University of Helsinki, SF-00710 Helsinki, Finland
}

\begin{abstract}
Studies of root nodule bacteria isolated from Galega orientalis and Galega officinalis are reviewed, and as a result a new species, Rhizobium galegae, is proposed. The type strain of the species is $R$. galegae HAMBI 540 (= ATCC 43677), which forms nitrogen-fixing root nodules on $G$. orientalis. Deoxyribonucleic acid homology distinguishes $R$. galegae from other rhizobia, whereas nodulation of Galega sp. and sensitivity to phage gal $1 / \mathbf{R}$ phenotypically separate the strains currently included in the species from other members of the genus Rhizobium. Other criteria supporting the formation of a new species include ribosomal ribonucleic aciddeoxyribonucleic acid homology data, protein and lipopolysaccharide patterns, serological properties, and numerical taxonomy data.
\end{abstract}

Root nodule bacteria are able to penetrate the roots of primarily leguminous plants. As a result of the infection, a specific structure, the root nodule, is formed. Once established within a nodule, the bacteria reduce atmospheric nitrogen to ammonia, which is transported to the plant. The present classification of root nodule bacteria, as described in Bergey's Manual of Systematic Bacteriology, separates the fast- and slow-growing organisms into two genera, Rhizobium and Bradyrhizobium (4). The fast-growing rhizobia are divided into three species, Rhizobium leguminosarum, Rhizobium meliloti, and Rhizobium loti, with $R$. leguminosarum comprising three biovars $(R$. leguminosarum biovar trifolii, $R$. leguminosarum biovar phaseoli, and $R$. leguminosarum biovar viciae). In addition, fast-growing rhizobia that nodulate soybeans have recently been assigned to a new species, Rhizobium fredii (12). The taxonomic criteria and methods used currently in the classification of the family Rhizobiaceae include numerical taxonomy, guanine-pluscytosine content, deoxyribonucleic acid (DNA) homology, protein patterns, serology, phage typing, composition of extracellular polysaccharides, plasmid transfer, and plant infection. The cross-inoculation test, which was used previously as a major taxonomic criterion, is now used only to complement other methods (4).

Fast-growing root nodule bacteria which nodulate the plant species Galega orientalis and Galega officinalis (goat's rue) were first studied by Hauke-Pacewiczowa (2) and Proctor (10); these authors claimed that the Galega rhizobia belong to $R$. leguminosarum and "the fast-growing lupine-cowpea complex" (now recognized as $R$. loti), respectively. However, results from more recent and extensive studies, conducted because of the potential agricultural properties of $G$. orientalis $(5,8,13)$, disagree with those of Hauke-Pacewiczowa (2) and Proctor (10). DNA homology, ribosomal ribonucleic acid-DNA hybridization, lipopolysaccharide and protein pattern, serology, phage typing, and cross-nodulation experiments all have shown that the $G a$ lega rhizobia form a homologous group of fast-growing rhizobia which is not closely related to the currently recognized Rhizobium species $(3,6,7,9,9 \mathrm{a}, 9 \mathrm{~b}, 15)$.

Rhizobium galegae sp. nov. Rhizobium galegae (ga.le'gae. M.L. fem. gen. n. galegae, of Galega). Short, gram-negative, nonsporeforming rods which are motile by means of one or two polar or subpolar flagella (Fig. 1). In nitrogenfixing nodules the cells are elongated bacteroids, and some are branched $(6,9 a)$. Colonies on Vincent yeast-mannitol agar (14) are more than $1.0 \mathrm{~mm}$ in diameter after 7 days at $28^{\circ} \mathrm{C}$. The maximum growth temperature is 33 to $37^{\circ} \mathrm{C}$. The cells grow in the presence of $0.5 \% \mathrm{NaCl}$ but not in the presence of $2.0 \% \mathrm{NaCl}$. A majority of the strains studied form a serum zone and give an alkaline reaction in litmus milk. They hydrolyze urea but do not precipitate calcium glycerophosphate, nor do they reduce nitrate. They require calcium panthotenate but not thiamine for growth. The following carbon sources are readily utilized in defined medium (def 9 medium [7]), with the formation of acidic end products: D-galactose, lactose, L-arabinose, dulcitol, raffinose, D-xylose, trehalose, L-rhamnose, sorbitol, maltose, D-glucose, D-fructose, and mannitol. The response to sucrose and citrate is weaker. The intrinsic antibiotic resistance patterns of $R$. galegae strains show fairly high resistance to trimethoprim and bacitracin and low resistance to neomycin and chloramphenicol (7). Numerical taxonomy separates the $R$. galegae strains from the previously described rhizobial species (7).

The guanine-plus-cytosine content of the DNA of $R$. galegae is $63 \mathrm{~mol} \%$ (7). Data from DNA hybridizations in which DNAs from strains HAMBI $540^{\mathrm{T}}$ ( $\mathrm{T}=$ type strain), HAMBI 1141, and galNW3 are used show that the $R$. galegae strains form a uniform DNA homology group, which

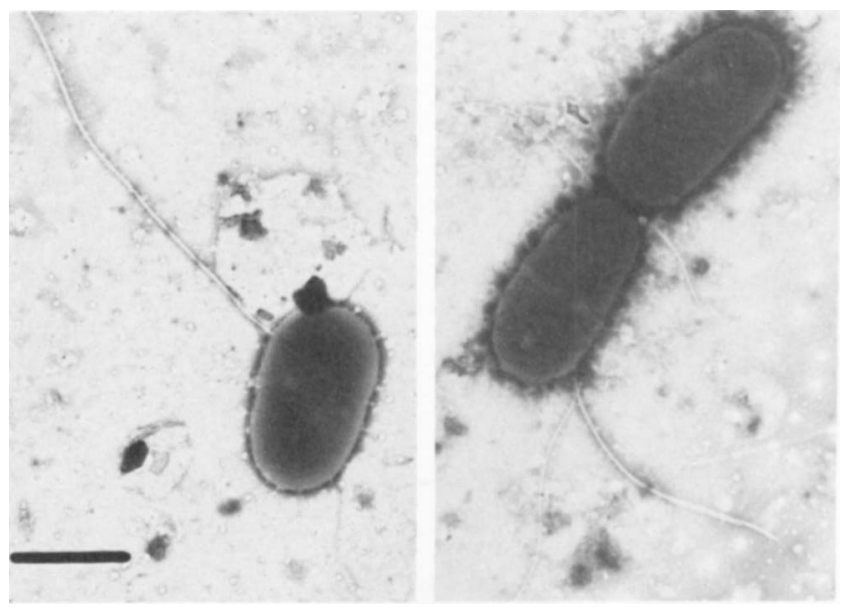

FIG. 1. Electron micrographs of $R$. galegae HAMBI $540^{\mathrm{T}}$. Negative staining of 16 -h-old cells from a nonagitated broth culture. Bar $=1 \mu \mathrm{m}$. 
TABLE 1. Mean relative levels of DNA homology between

$R$. galegae reference strains HAMBI $540^{\mathrm{T}}$, HAMBI 1141 , and galNW3 and other rhizobia and bradyrhizobia

\begin{tabular}{lccc}
\hline \multirow{2}{*}{\multicolumn{1}{c}{ Taxon }} & \multicolumn{2}{c}{ \% Homology with reference strain: } \\
\cline { 2 - 4 } & $\begin{array}{c}\text { HAMBI } \\
540^{\mathrm{Ta}}\end{array}$ & $\begin{array}{c}\text { HAMBI } \\
1141^{b}\end{array}$ & galNW3 $^{b}$ \\
\hline R. galegae & $77 \pm 9^{c}$ & $79 \pm 14$ & $85 \pm 9$ \\
R. meliloti & & $8 \pm 6$ & $22 \pm 1$ \\
R. leguminosarum & $22 \pm 4$ & $22 \pm 7$ & $44 \pm 1$ \\
R. loti & $16 \pm 4$ & 10 & $16 \pm 2$ \\
Rhizobium sp. (Coronilla) & & 14 & 25 \\
Rhizobium sp. (Leucaena) & & $10 \pm 2$ & 24 \\
Bradyrhizobium sp. & $20 \pm 9$ & 2 & $12 \pm 5$ \\
\hline
\end{tabular}

${ }^{a}$ Data from reference 6

${ }^{b}$ Data calculated from reference 15 .

c Mean \pm standard deviation.

is not closely related to other Rhizobium or Bradyrhizobium species (Table 1) $(6,15)$. Thus, DNA homology can be used to distinguish $R$. galegae strains from other rhizobial species. Ribosomal ribonucleic acid-DNA hybridization data place $R$. galegae in a separate group (group III) within the genus Rhizobium (3); $R$. meliloti, $R$. fredii, and $R$. leguminosarum form group I, and $R$. loti forms group II. All of the $R$. galegae strains tested contain at least one very large plasmid, and some strains also contain additional smaller plasmids (Fig. 2).

All strains produce extracellular polysaccharide (unpublished data). The soluble protein and lipopolysaccharide

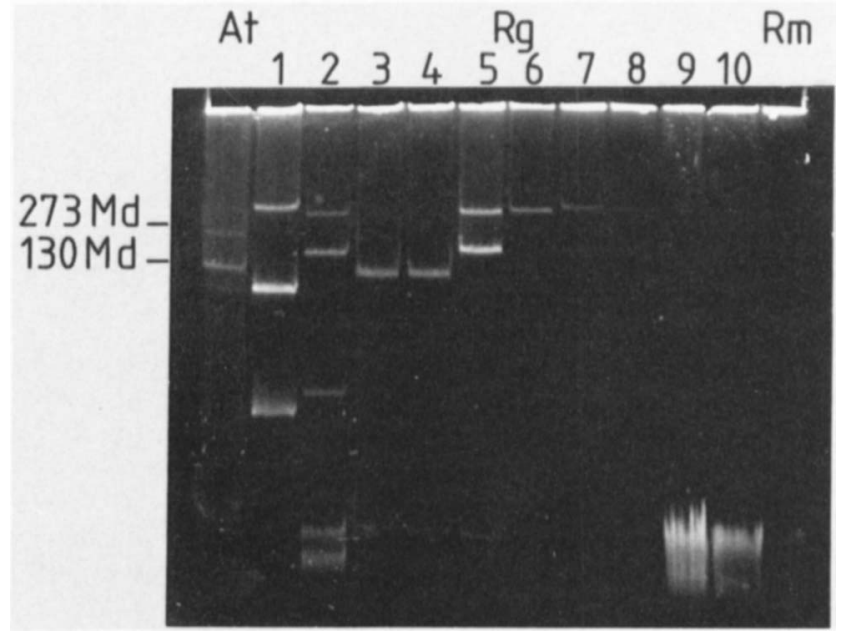

FIG. 2. Plasmid profiles of $R$. galegae strains. Lane $1, R$. gale gae HAMBI 1146; lane 2, $R$, galegae HAMBI 1145; lane $3, R$. galegae HAMBI 1143; lane 4, $R$. galegae HAMBI 1141; lane $5, R$. galegae HAMBI 1183; lane 6, $R$. galegae HAMBI 1185; lane 7, $R$. galegae HAMBI 503; lane 8, $R$. galegae HAMBI 490; lane $9, R$. galegae HAMBI 1147; lane $10, R$, galegae HAMBI $540^{\mathrm{T}}$. The controls used were Agrobacterium tumefaciens C58 (lane At) and $R$. meliloti $\mathrm{Rm} 1021$ (lane $\mathrm{Rm}$ ). Md, Megadalton. The method used was the Eckhardt method (1) as modified by Rosenberg et al. (11).

TABLE 2. Galega rhizobia included in the species $R$. galegae

\begin{tabular}{|c|c|c|}
\hline Strain $^{a}$ & Geographic origin or source ${ }^{b}$ & Reference(s) \\
\hline HAMBI $540^{\mathrm{T}}\left(=\text { gal1261 } 1^{\mathrm{T}}=\text { ATCC } 43677^{\mathrm{T}}\right)^{\mathrm{c}}$ & Finland & $3,5-7,9 b$ \\
\hline HAMBI 1174 (= gal1261R) & $\mathrm{Sm}^{\mathrm{r}}$ and $\mathrm{Spc}^{\mathrm{r}}$ derivative of HAMBI $540^{\mathrm{T}}$ & $7-9 a$ \\
\hline HAMBI $1155(=$ galE $)$ & USSR & 6,7 \\
\hline HAMBI 1147 (= gal129) & Finland & $3,6,7,15$ \\
\hline HAMBI $1460(=$ gor 3$)$ & Finland & \\
\hline HAMBI 1462 (= gal302) & USSR & $9 b$ \\
\hline HAMBI 1428 (= K-092) & USSR & $9 b$ \\
\hline HAMBI 1141 (= gal1) & New Zealand & $6,7,9 b, 15$ \\
\hline HAMBI 1207 (= galls) & $\mathrm{Sm}^{\mathrm{r}}$ derivative of HAMBI 1141 & \\
\hline HAMBI 1143 (= gal3) & New Zealand & $6,7,15$ \\
\hline HAMBI $1208(=$ gal3s $)$ & $\mathrm{Sm}^{\mathrm{r}}$ derivative of HAMBI 1143 & \\
\hline HAMBI $1144(=$ gal7) & New Zealand & $6,7,15$ \\
\hline HAMBI 1145 (= gal12) & New Zealand & $6,7,9 b, 15$ \\
\hline HAMBI 1146 (= gal14) & New Zealand & $6,7,15$ \\
\hline HAMBI 1122 (= NZP 5067) & New Zealand & 6 \\
\hline HAMBI 1151 (= NZP 5068) & New Zealand & $6,7,9 b$ \\
\hline HAMBI $490(=$ galB7i) & Finland & $6,7,9-9 b, 15$ \\
\hline HAMBI $1209(=$ galB7is $)$ & $\mathrm{Sm}^{\mathrm{r}}$ derivative of HAMBI 490 & \\
\hline HAMBI $503(=59 \mathrm{~A} 2)$ & United States & $6,7,15$ \\
\hline HAMBI $1183(=\mathrm{G} 6)$ & England & $7,9 b$ \\
\hline HAMBI 1184 (= G8) & England & 7 \\
\hline HAMBI $1185(=$ G9) & England & 7 \\
\hline HAMBI $1186(=$ G10) & England & \\
\hline HAMBI $1187(=$ G11) & England & \\
\hline HAMBI $1189(=$ G12) & England & \\
\hline HAMBI $1190(=$ G15) & England & \\
\hline HAMBI $1191(=$ G16) & England & \\
\hline galNW1 & New Zealand & 15 \\
\hline galNW2 & New Zealand & 15 \\
\hline galNW3 & New Zealand & 15 \\
\hline
\end{tabular}

"HAMBI, Culture Collection of the Department of Microbiology, University of Helsinki, Helsinki, Finland; NZP, Division of Scientific and Industrial Research, Palmerston North, New Zealand.

${ }^{b} \mathrm{Sm}^{\mathrm{r}}$, Streptomycin resistant; $\mathrm{Spc}^{\mathrm{r}}$, spectinomycin resistant.

C Reference strain. 
patterns of $R$. galegae strains differ from those of other rhizobia. Antiserum raised against strain HAMBI $540^{\mathrm{T}}$ (isolated from $G$. orientalis) reacts with lipopolysaccharides from all of the $R$. galegae strains tested. Immunoblotting of whole-cell soluble proteins reveals two protein bands which are unique to $R$. galegae strains $(9 \mathrm{~b})$.

Cells can be infected by bacteriophages which are host range specific. Susceptibility to phage gal $1 / R$ can be used to distinguish $R$. galegae strains from other fast- and slowgrowing root nodule bacteria $(6,7)$.

Nitrogen-fixing (effective) nodules are formed by strains isolated from $G$. orientalis on that plant and by strains isolated from $G$. officinalis on their original host. Strains isolated from $G$. orientalis form ineffective nodules on $G$. officinalis and vice versa. $R$. galegae strains do not infect the other leguminous plants tested. Plants of Galega spp. are only occasionally infected by other rhizobia, but when infection does take place, no nitrogen fixation occurs $(6,9$, $9 a)$. Thus, in addition to typing with phage gal $1 / R$, effective nodulation of $G$. orientalis or $G$. officinalis phenotypically distinguishes $R$. galegae from other Rhizobium species.

The strains which presently can be included in the species $R$. galegae are listed in Table 2 .

The type strain of $R$. galegae is strain HAMBI 540 (isolated from $G$. orientalis), a culture of which has been deposited in the American Type Culture Collection as strain ATCC 43677. This strain conforms to the description given above for the species with respect to morphology, physiology, guanine-plus-cytosine content, DNA and ribosomal ribonucleic acid homology, serology, and cross-nodulation. It is a Finnish field isolate derived from strain HAMBI 1155 (= galE), which was originally isolated by Debora Gurfel in Estonia. It is used as an inoculant in field experiments with goat's rue (5). It is lysed by phages gal $1 / \mathrm{R}$, gal $1 / \mathrm{OW}$, gal $3 / \mathrm{R}$, and gal 3/OW (6) and is the isolation host of phages gal 1261/M and gal 1261/V (7; J. J. Patel and K. Lindström, Abstr. Global Impacts Appl. Microbiol. VII, abstr. no. B16, p. 86, 1985). It is not lysed by bacteriophages which lyse $R$. leguminosarum, $R$. meliloti, and $R$. loti $(6,7)$.

I thank all those individuals who contributed to the $R$. galegae research and Päivi Lipsanen for Fig. 1.

This work was mainly supported by the Academy of Finland and the OECD.

\section{LITERATURE CITED}

1. Eckhardt, T. 1978. A rapid method for the identification of plasmid desoxyribonucleic acid in bacteria. Plasmid 1:584-588.

2. Hauke-Pacewiczowa, T. 1952. Szczepionki dla Galega officinalis. Acta Microbiol. Pol. 1:37-39.
3. Jarvis, B. D. W., M. Gillis, and J. De Ley. 1986. Intra- and intergenic similarities between the ribosomal ribonucleic acid cistrons of Rhizobium and Bradyrhizobium species and some related bacteria. Int. J. Syst. Bacteriol. 36:129-138.

4. Jordan, D. C. 1984. Family III. Rhizobiaceae Conn 1938, p. 234-244. In N. R. Krieg and J. G. Holt (ed.), Bergey's manual of systematic bacteriology, vol. 1. The Williams \& Wilkins Co., Baltimore.

5. Lindström, K. 1984. Analysis of factors affecting in situ nitrogenase $\left(\mathrm{C}_{2} \mathrm{H}_{2}\right)$ activity of Galega orientalis, Trifolium pratense and Medicago sativa in temperate conditions. Plant Soil 79: 329-341.

6. Lindström, K., B. D. W. Jarvis, P. E. Lindström, and J. J. Patel. 1983. DNA homology, phage-typing, and cross-nodulation studies of rhizobia infecting Galega species. Can. J. Microbiol. 29:781-789.

7. Lindström, K., and S. Lehtomäki. 1988. Metabolic properties, maximum growth temperature and phage sensitivity of Rhizobium sp. (Galega) compared with other fast-growing rhizobia. FEMS Microbiol. Lett. 50:277-287.

8. Lindström, K., M. L. Sarsa, J. Polkunen, and P. Kansanen. 1985. Symbiotic nitrogen fixation of Rhizobium (Galega) in acid soils, and its survival in soil under acid and cold stress. Plant Soil 87:293-302.

9. Lipsanen, P., and K. Lindström. 1986. Specificity of Rhizobium (Galega)-Galega interaction, p. 113-114. In B. Lugtenberg (ed.), Recognition in microbe-plant symbiotic and pathogenic interactions. North Atlantic Treaty Organization ASI Series, vol. $\mathrm{H} 4$.

9a.Lipsanen, P., and K. Lindström. 1988. Infection and root nodule structure in the Rhizobium galegae sp. nov.-Galega sp. symbiosis. Symbiosis 6:81-96.

9b.Lipsanen, P., and K. Lindström. 1989. Lipopolysaccharide and protein patterns of Rhizobium sp. (Galega). FEMS Microbiol. Lett. 58:323-328.

10. Proctor, M. H. 1963. Cross-inoculation group relationships of Galega officinalis. N.Z. J. Bot. 1:419-425.

11. Rosenberg, C., F. Casse-Delbart, I. Duscha, M. David, and C. Boucher. 1982. Megaplasmids in the plant-associated bacteria Rhizobium meliloti and Pseudomonas solanacearum. J. Bacteriol. 150:402-406.

12. Scholla, M. H., and G. H. Elkan. 1984. Rhizobium fredii sp. nov., a fast-growing species that effectively nodulates soybeans. Int. J. Syst. Bacteriol. 34:484-486.

13. Varis, E. 1986. Goat's rue (Galega orientalis Lam.), a potential pasture legume for temperate conditions. J. Agric. Sci. Finland 58:83-101.

14. Vincent, J. M. 1970. A manual for the practical study of root-nodule bacteria. International Biological Program Handbook 15. Blackwell Scientific Publications, Oxford, England.

15. Wedlock, D. N., and B. D. W. Jarvis. 1986. DNA homologies between Rhizobium fredii, rhizobia that nodulate Galega sp., and other Rhizobium and Bradyrhizobium species. Int. J. Syst. Bacteriol. 36:550-558. 